\title{
PENERAPAN METODE SIMPLE ADDITIVE WEIGHTING PADA APLIKASI E-KUESIONER PENILAIAN KINERJA GURU
}

\author{
Dimas Aulia Pudjie Prasetya', Petrus Sokibi², Wanda Ilham ${ }^{3}$ \\ 1,2,3Program Studi Teknik Informatika, \\ Fakultas Teknologi dan Informasi, Universitas CIC, Cirebon, Indonesia \\ 1'dimasauliap07@gmail.com, ${ }^{2}$ petrus.sokibi@cic.ac.id, ${ }^{3}$ wandailham@cic.ac.id
}

\begin{abstract}
ABSTRAK
Standar pendidik atau tenaga kependidikan merupakan salah satu strandar dari standar pendidikan di Indonesia. Standar pendidik dapat menentukan kualitas yang dihasilkan dari pembelajaran yang dilakukannya. Dalam menentukan kualitas pendidik maka harus ada penilaian terhadap kinerja guru. Penilaian kinerja guru biasanya dilakukan oleh Kepala Sekolah dan Ketua Yayasan, hal tersebut menimbulkan terjadinya penilaian secara subjektif. Untuk itu dibutuhkan sebuah sistem yang menunjang keputusan untuk menentukan kualitas dari pendidik atau guru sehingga penilaian dapat lebih adil dan bersifat objektif. Sistem yang menunjang keputusan untuk menentukan kualitas guru ini menggunakan metode Simple Additive Weighting (SAW). Sistem ini berbasis web dan android yang dibuat dengan memanfaatkan seperangkat komputer yaitu laptop dan menggunakan bahasa pemrograman PHP dan Java serta menggunakan database MySQL. Sistem ini dapat melakukan kinerja guru yang melibatkan siswa sebagai responden untuk mengisi kuesioner penilaian kinerja guru. Dengan melibatkan siswa yang dalam hal ini sangat berkaitan erat dengan cara pengajaran dari guru yang bersangkutan dapat lebih mengetahui kualitas guru tersebut dan menghasilkan penilaian kinerja yang cukup objektif.
\end{abstract}

Kata Kunci: Sistem Pendukung Keputusan, Kinerja Guru, Web, Android.

\begin{abstract}
The standard of educators or educational personnel is one of the standards of education standards in Indonesia. Educator standards can determine the quality that results from the learning he does. In determining the quality of educators, there must be an assessment of teacher performance. Teacher performance appraisal is usually carried out by the Principal and Chair of the Foundation, this results in a subjective assessment. For that we need a system that supports decisions to determine the quality of educators or teachers so that assessments can be fair and objective. This decision support system to determine teacher quality uses the Simple Additive Weighting (SAW) method. This web and Android-based system is made using a computer, namely a laptop and uses the programming languages PHP and Java and uses the MYSQL database. This system can perform teacher performance involving students as respondents to fill out a teacher performance appraisal questionnaire. By involving students who in this case are closely related to the teaching method of the teacher concerned can better know the quality of the teacher and produce a fairly objective performance assessment.
\end{abstract}

Keywords: Decision Support System, Teacher Performance, Web, Android. 


\section{PENDAHULUAN}

Penilaian merupakan salah satu standar dari delapan standar pendidikan di Indonesia. Kedelapan standar itu adalah standar isi, standar proses, standar kompetensi lulusan, standar pendidik dan tenaga kependidikan, standar sarana dan prasarana, standar pengelolahan, standar pembiayaan dan standar penilaian pendidikan. Standar penilaian memiliki tujuan untuk mengukur keberhasilan pembelajaran sehingga bermanfaat bagi peserta didik, yaitu untuk mengukur sejauh mana peserta didik mampu menyerap materi yang telah disampaikan. Sedangkan bagi guru, penilaian bermanfaat untuk umpan balik dari hasil kinerja pembelajaran yang telah dilakukannya. Adapun pedoman dalam standar penilaian guru, ialah Peraturan Menteri Pendidikan Nasional Nomor 16 Tahun 2007 tentang Standar Kualifikasi dan Kompetensi Guru [1].

Kinerja mengajar guru menjadi sangat penting karena mempengaruhi kualitas pendidikan disekolah, untuk itu berbagai upaya dilakukan sekolah dalam rangka meningkatkan kinerja mengajar guru, karena penilaian merupakan indikator keberhasilan guru dalam proses pembelajaran [2]. Penilaian mengacu pada proses menetapkan nilai pada suatu kegiatan, keputusan, proses, orang, dan objek. Penilaian tidak selalu dilakukan melalui proses pengukuran tetapi dapat dilakukan dengan cara membandingkannya dengan kriteria-kriteria yang berlaku tanpa perlu melakukan pengukuran terlebih dahulu.

Permasalahan guru kurang berkompetensi dalam bidangnya memang bukan hal yang asing untuk kita simak. Akan tetapi jika permasalahan ini dianggap semakin biasa, maka pemecahannya pun juga biasa-biasa saja, padahal konsekuensi dari hal ini adalah luar biasa karena akan berdampak pada peserta didik. Kemajuan pada teknologi saat ini sudah menyebar disemua aspek kehidupan dan profesi, sudah seharusnya jika dalam melakukan penilaian menggunakan sistem yang terkomputerisasi untuk mempermudah penilaian dan mengevaluasi kinerja guru. Namun sayangnya masih jarang yang memanfaatkan kemajuan teknologi saat ini. Salah satunya adalah Sekolah Menengah Kejuruan ASYIFA DEPOK yang terletak di Desa Cikeduk Kecamatan Depok Kabupaten Cirebon, tidak adanya sistem yang dibuat dalam bentuk digital membuat penilaian setiap guru kebanyakan hanya sepihak, dalam menilai dan mengevaluasi kinerja guru dilakukan dengan melihat aktivitas guru secara langsung dan meminta pendapat karyawan yang lain tentang guru yang akan dinilai kinerjanya. Namun, cara seperti ini dinilai kurang efektif, kurang adil, dan masih bersifat subjektif.

Oleh karena itu untuk mengatasi masalah tersebut perlu adanya sistem yang mampu mengevaluasi kinerja guru pada SMK ASYIFA DEPOK. Salah satu metode yang dapat menilai kinerja guru adalah Metode Simple Additive Weighting (SAW), Metode SAW adalah suatu metode yang mencari penjumlahan terbobot dari rating kinerja pada setiap alternatif pada semua atribut [3]. Dengan menggunakan SAW maka dapat menentukan siapa guru melakukan tanggung jawabnya dengan sungguh-sungguh berdasarkan kriteri dan bobot yang sudah ditentukan.
Berdasarkan permasalahan yang dijelaskan diatas, maka penulis tertarik dan terdorong untuk membuat sistem dengan judul "Penerapan Metode Simple Additive Weighting Pada Aplikasi E-Kuesioner Penilaian Kinerja Guru" yang digunakan untuk membantu menilai dan mengevaluasi kinerja guru dengan studi kasus: SMK Asyifa Depok.

\section{TINJAUAN PUSTAKA}

\subsection{Penilaian Kinerja}

Analisis Penilaian kinerja adalah upaya guna mengadakan pengukuran atas kinerja dari setiap karyawan perusahaan. Hal ini dikaitkan dengan tingkat produktivitas dan efektivitas kerja dari karyawan tersebut dalam menghasilkan karya tertentu, sesuai dengan Job Description (deskripsi tugas) yang diberikan perusahaan kepada karyawan yang bersangkutan [5].

\subsection{Guru}

Guru adalah pendidik profesional dengan tugas utamanya mendidik, mengajar, pembimbing mengarang, melatih, menilai, dan mengevaluasi peserta didik pada pendidikan anak usia dini jalur pendidikan formal, Pendidikan dasar, dan Pendidikan menengah [6].

\subsection{Sistem Penunjang Keputusan}

Sistem pendukung keputusan adalah sistem berbasis komputer yang membantu para pengambil keputusan mengatasi berbagai masalah melalui interaksi langsung dengan sejumlah basis data (database) dan perangkat lunak analitik. Sistem pendukung keputusan adalah bagian dari sistem informasi berbasis komputer (termasuk sistem berbasis pengetahuan (manajemen pengetahuan) yang dipakai untuk mendukung pegambilan keputusan dalam suatu organisasi atau perusahaan [7].

\section{4. $\quad$ Simple Additive Weighting}

Simple Additive Weighting sering juga dikenal dengan istilah metode penjumlahan berbobot. Konsep dasar metode Simple Additive Weighting adalah mencari penjumlahan terbobot dari rating kinerja pada setiap alternatif pada semua atribut [3]. Metode Simple Additive Weighting (SAW) membutuhkan proses normalisasi matriks keputusan (X) ke suatu skala yang dapat diperbandingkan dengan semua rating alternatif yang ada [3]. Diberikan persamaan sebagai berikut :

$R_{\mathrm{ij}}=\frac{X_{i j}}{\operatorname{Max}_{i} X_{i j}} \mathrm{Jika} \mathrm{J}$ adalah atribut keuntungan (Benefit)

$R_{\mathrm{ij}}=\frac{\operatorname{Min}_{i} X_{i j}}{X_{i j}} \mathrm{Jika} \mathrm{J}$ adalah atribut keuntungan $($ Cost $)$

Keterangan setiap kriteria:

$\mathrm{R}_{\mathrm{ij}} \quad$ : Nilai rating kinerja ternormalisasi.

$\mathrm{R}_{\mathrm{ij}} \quad$ : Nilai atribut yang dimiliki dari.

$\operatorname{Max} X_{\mathrm{ij}}$ : Nilai terbesar dari setiap kriteria.

Min $X_{\mathrm{ij}}$ : Nilai terkecil dari setiap kriteria.

Benefit : Jika nilai terbesar adalah terbaik. 
Cost : Jika nilai terkecil adalah terbaik.

Adapun hasil akhir nilai preferensi (Vi) diperoleh dari penjumlahan dari perkalian elemen baris matrik ternormalisasi (R) dengan bobot preferensi (W) yang bersesuaian elemen kolom matrik $(\mathrm{W})$.

$V_{\mathrm{i}}=\sum_{j=1}^{n} W_{j} R_{i j}$

Keterangan :

$V_{i} \quad$ : Rangking untuk setiap alternative.

$W_{j} \quad$ : Nilai bobot dari setiap kriteria.

$r_{i j} \quad$ : Nilai rating kinerja ternormalisasi.

\section{METODOLOGI PENELITIAN}

3.1. Perhitungan Metode SAW

a. Data Hasil Penilaian

Tabel 1. Data Penilaian

\begin{tabular}{cccccc}
\hline \multirow{2}{*}{ No. } & \multirow{2}{*}{ Nama Guru } & \multicolumn{4}{c}{ Nilai } \\
\cline { 3 - 6 } & & C1 & C2 & C3 & C4 \\
\hline 1 & Nurhayati A & 3,3 & 4 & 3 & 3,75 \\
2 & Aziz Muslimin & 2,8 & 3,6 & 3,5 & 3 \\
3 & Eddo Invonindo & 3,8 & 3,6 & 3,3 & 4 \\
4 & Suhartini & 3,6 & 4.2 & 3,25 & 4 \\
5 & Johar Aripin & 2,8 & 3,6 & 4,1 & 3,5 \\
6 & Nunung Ruaenipah & 4,2 & 4 & 4,1 & 3 \\
\hline Sumber: SMK Asyifa Depok & & & &
\end{tabular}

b. Kriteria dan Bobot

Menentukan kriteria-kriteria yang akan dijadikan acuan dalam pengambilan keputusan, yaitu $\mathrm{Cj}$. Langkah kedua memberikan nilai setiap alternatif Ai pada setiap kriteria ynag sudah ditentukan, dimana nilai tersebut diperoleh berdasarkan nilai crisp; $i=1,2, \ldots, x$ dan $j=1,2, \ldots, n$

\section{Alternatif}

A1 = Nurhayati A., S.pd

A2 = Aziz Muslimin., S.pd

A3 = Eddo Invonindo., S.pd

A4 = Suhartini., S.pd

A5 = Johar Aripin., S.Ag

A6 = Nunung Ruaenipah., S.pd

Tabel 2. Kriteria

\begin{tabular}{cccc}
\hline Kode & Nama Kriteria & Tipe & Bobot \\
\hline C1 & Pedagogik & Benefit & $40 \%=0.4$ \\
C2 & Kepribadian & Cost & $20 \%=0.2$ \\
C3 & Sosial & Cost & $10 \%=0.1$ \\
C4 & Profesional & Benefit & $30 \%=0.3$ \\
\hline
\end{tabular}

\section{c. Rating Kecocokan}

Dari kriteria yang disebutkan diatas, kemudian dibuatkan rating kecocokan dari setiap kriteria beserta bobot-bobotnya yang dikonversikan dengan bilangan Fuzzy.
Tabel 3. Skala Rating Kecocokan

\begin{tabular}{ccc}
\hline Keterangan & Range & Bobot \\
\hline Sangat Kurang & $<=1$ & \\
(SK) & $>1$ dan $<=2$ & 0,2 \\
Kurang (K) & $>2$ dan $<=3$ & 0.4 \\
Cukup (C) & $>3$ dan $<=4$ & 0.8 \\
Baik (B) & $>4$ & 1 \\
Sangat Baik (SB) &
\end{tabular}

Berdasarkan tabel data penilaian diatas, maka dapat dibuat tabel rating kecocokan dari setiap alternatif pada setiap kriteria.

Tabel 4. Rating Kecocokan Alternatif

\begin{tabular}{ccccc}
\hline \multirow{2}{*}{ Alternatif } & \multicolumn{4}{c}{ Nilai } \\
\cline { 2 - 5 } & C1 & C2 & C3 & C4 \\
\hline A1 & 0,8 & 0,8 & 0,6 & 0,8 \\
A2 & 0,6 & 0,8 & 0,8 & 0,6 \\
A3 & 0,8 & 0,8 & 0,8 & 0,8 \\
A4 & 0,8 & 1 & 0,8 & 0,8 \\
A5 & 0,6 & 0,8 & 1 & 0,8 \\
A6 & 1 & 0,8 & 1 & 0,6 \\
\hline
\end{tabular}

\section{d. Normalisasi setiap Kriteria}

Melakukan proses perhitungan normaliasi berdasarkan skala yang dapat dibandingkan dengan semua rating alternatif yang ada. Kinerja ternomalisasi dari alternatif $\mathrm{Ai}$ pada atribut $\mathrm{Cj},=1$, $2, \ldots \ldots, \mathrm{n}$.

1) Kriteria Pedagogik (C1)

Dari kolom C1 nilai maksimalnya adalah "1", maka tiap baris dari kolom $\mathrm{C} 1$ dibagi oleh nilai maksimalnya kolom $\mathrm{C}$.

$\mathrm{R} 11=\frac{0,8}{1}=0,8$
$\mathrm{R} 12=\frac{0,6}{1}=0,6$

2) Kriteria Kepribadian (C2)

Dari kolom C2 nilai minimumnya adalah " 0,8 ”, maka tiap baris dari kolom $\mathrm{C} 2$ dibagi oleh nilai maksimalnya kolom $\mathrm{C}$.

$\mathrm{R} 21=\frac{0,8}{0,8}=1$

$\mathrm{R} 22=\frac{0,8}{0,8}=1$

3) Kriteria Sosial (C3)

Dari kolom C3 nilai minimumnya adalah " 0,6 ", maka tiap baris dari kolom C3 dibagi oleh nilai maksimalnya kolom $\mathrm{C}$.

$\mathrm{R} 31=\frac{0,6}{0,6}=1$

$\mathrm{R} 32=\frac{0,6}{0,8}=0,75$

4) Kriteria Profesional (C4)

Dari kolom C4 nilai maksimalnya adalah " 0,8 ", maka tiap baris dari kolom $\mathrm{C} 4$ dibagi oleh nilai maksimalnya kolom $\mathrm{C}$. 


$$
\begin{aligned}
& \mathrm{R} 41=\frac{0,8}{0,8}=1 \\
& \mathrm{R} 42=\frac{0,6}{0,8}=0,75
\end{aligned}
$$

Berdasarkan perhitungan diatas, maka didapatkan tabel normalisasi dari setiap alternatif sebagai berikut:

Tabel 5. Normalisasi Alternatif

\begin{tabular}{ccccc}
\hline \multirow{2}{*}{ Alternatif } & \multicolumn{4}{c}{ Nilai } \\
\cline { 2 - 5 } & C1 & C2 & C3 & C4 \\
\hline A1 & 0,8 & 1 & 1 & 1 \\
A2 & 0,6 & 1 & 0,75 & 0,75 \\
A3 & 0,8 & 1 & 0,75 & 1 \\
A4 & 0,8 & 0,8 & 0,75 & 1 \\
A5 & 0,6 & 1 & 0,6 & 1 \\
A6 & 1 & 1 & 0,6 & 0,75 \\
\hline
\end{tabular}

\section{e. Matriks Normalisasi}

Dari hasil tabel normalisasi dapat dibuatlah matriks ternormaliasi $\mathrm{R}$, yaitu:

$$
\mathrm{R}=\left[\begin{array}{cccc}
0,8 & 1 & 1 & 1 \\
0,6 & 1 & 0,75 & 0,75 \\
0,8 & 1 & 0,75 & 1 \\
0,8 & 0,8 & 0,75 & 1 \\
0,6 & 1 & 0,5 & 1 \\
1 & 1 & 0,5 & 0,75
\end{array}\right]
$$

\section{f. Perangkingan}

Untuk mencari nilai prefensi (Vi) dari setiap alternatif adalah dengan cara menjumlahkan hasil kali antara matriks ternormalisasi (R) dengan nilai bobot (W). Berikut ini merupakan persamaan untuk mencari nilai preferensi dari setiap alternatif yang telah ditentukan

$$
V_{\mathrm{i}}=\sum_{j=1}^{n} W_{j} R_{i j}
$$

Keterangan :

$V_{i} \quad$ : Rangking untuk setiap alternative.

$W_{j} \quad$ : Nilai bobot dari setiap kriteria.

$r_{i j} \quad$ : Nilai rating kinerja ternormalisasi

Untuk mencari alternatif terbaik maka hasil yang akan diperoleh sebagai berikut:

Bobot Kriteria $(\mathrm{W})=[0,40,20,10,3]$

$$
\begin{aligned}
\mathrm{V} 1 & =(0,4 * 0,8)+(0,2 * 1)+(0,1 * 1)+(0,3 * 1) \\
& =0,92 \\
\mathrm{~V} 2 & =(0,4 * 0,6)+(0,2 * 1)+(0,1 * 0,75)+ \\
& (0,3 * 0,75)=0,74 \\
\mathrm{~V} 3 & =(0,4 * 0,8)+(0,2 * 1)+(0,1 * 0,75)+(0,3 * 1) \\
& =0,895
\end{aligned}
$$

$$
\begin{aligned}
& \text { V4 }=(0,4 * 0,8)+(0,2 * 0,8)+(0,1 * 0,75)+ \\
&(0,3 * 1)=0,855 \\
& \text { V5 }=(0,4 * 0,6)+(0,2 * 1)+(0,1 * 0,6)+(0,3 * 1)= \\
& 0,8 \\
& \text { V6 }=(0,4 * 1)+(0,2 * 1)+(0,1 * 0,6)+(0,3 * 0,75) \\
&=0,885
\end{aligned}
$$

Sehingga hasil akhir perangkingan setiap alternatif sebagai berikut:

Tabel 6. Hasil Perhitungan

\begin{tabular}{ccc}
\hline Alternatif & Hasil & Rangking \\
\hline Nurhayati A & 0,92 & 1 \\
Eddo Invonindo & 0,895 & 2 \\
Nunung Ruaenipah & 0,885 & 3 \\
Suhartini & 0,855 & 4 \\
Johar Aripin & 0,8 & 5 \\
Aziz Muslimin & 0,74 & 6 \\
\hline
\end{tabular}

Berdasarkan hasil proses perangkingan diatas maka didapat nilai terbesar pada V1, sehingga alternatif $\mathrm{A} 1$ adalah alternatif yang terpilih sebagai alternatif terbaik dalam penilaian kinerja guru

\subsection{Perancangan Sistem}

Perancangan sistem menjelaskan mengenai gambaran sistem yang diusulkan untuk aplikasi penilaian kinerja guru di SMK Asyifa Depok.

\section{a. Flowchart}

Flowchart menggambarkan bagan yang menjelaskan alur kerja penggunaan sistem secara keseluruhan. Dimulai dari siswa mengisi kuesioner penilaian guru. Hasil kuesioner disimpan ke dalam database, kemudian dihitung dengan metode SAW untuk mendapat hasil perangkingan penilaian kinerja guru yang dapat dilihat oleh Admin, Kepala Sekolah/Ketua Yayasan, dan Guru pengajar.

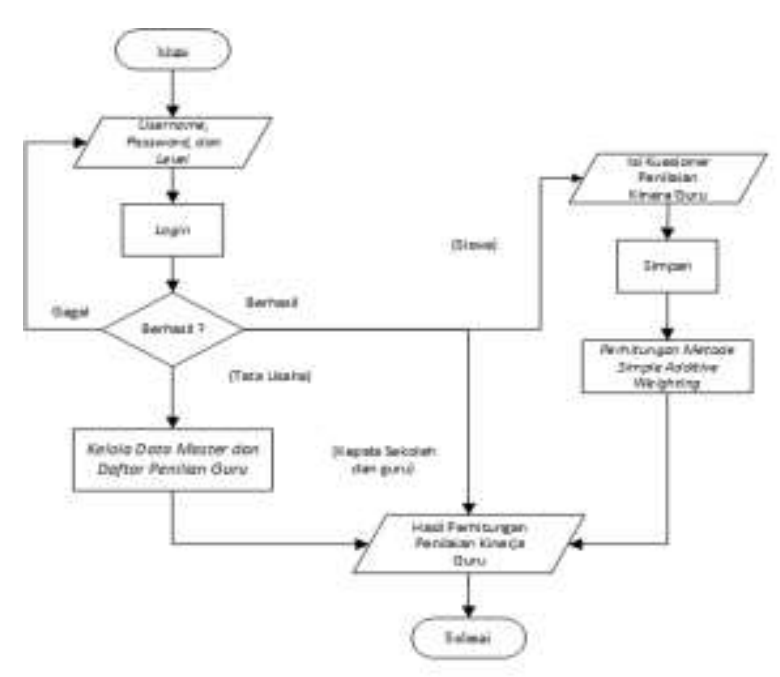


Gambar 1. Flowchart Penilaian Kinerja Guru

\section{b. Use Case Diagram}

Aktor yang terlibat didalam use-case diagram yang akan dibuat adalah:

1) Admin/Staff TU

2) Kepala Sekolah/Ketua Yayasan

3) Guru Pengajar

4) Siswa

Berikut ini adalah Use case diagram pada sistem ini diagambarkan berdasarkan Aktor dalam aktivitasnya adalah:

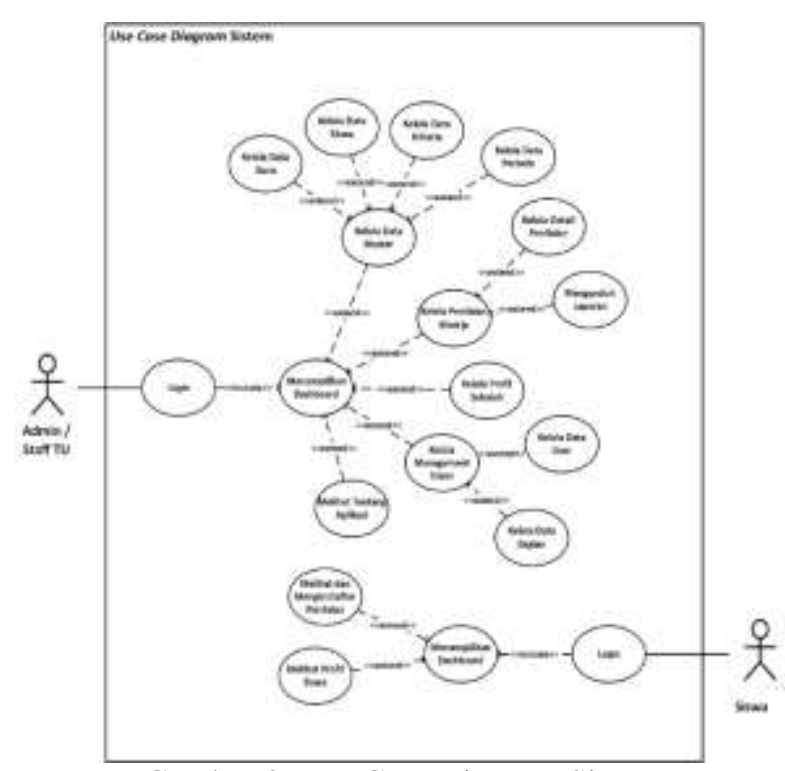

Gambar 2. Use Case Diagram Sistem

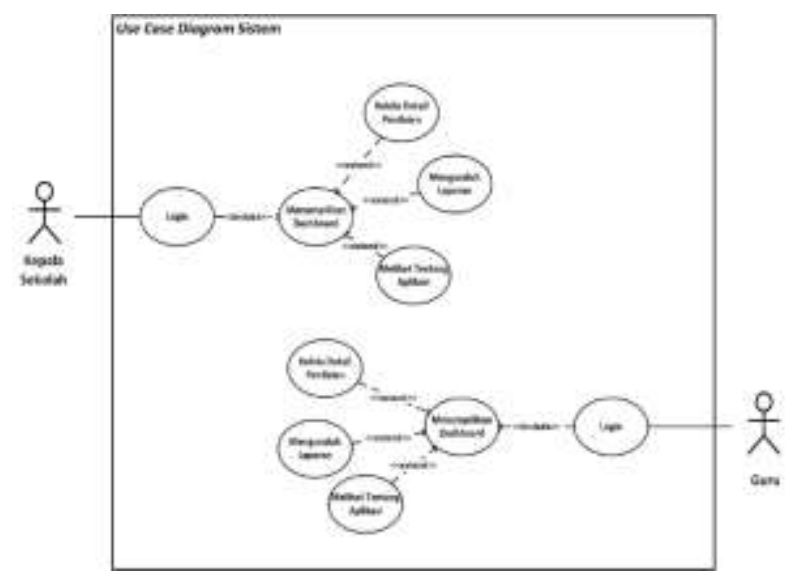

Gambar 2. Use Case Diagram Sistem (lanjutan)

c. Class Diagram

Berikut adalah class diagram Sistem penilaian kinerja guru yang dibangun:

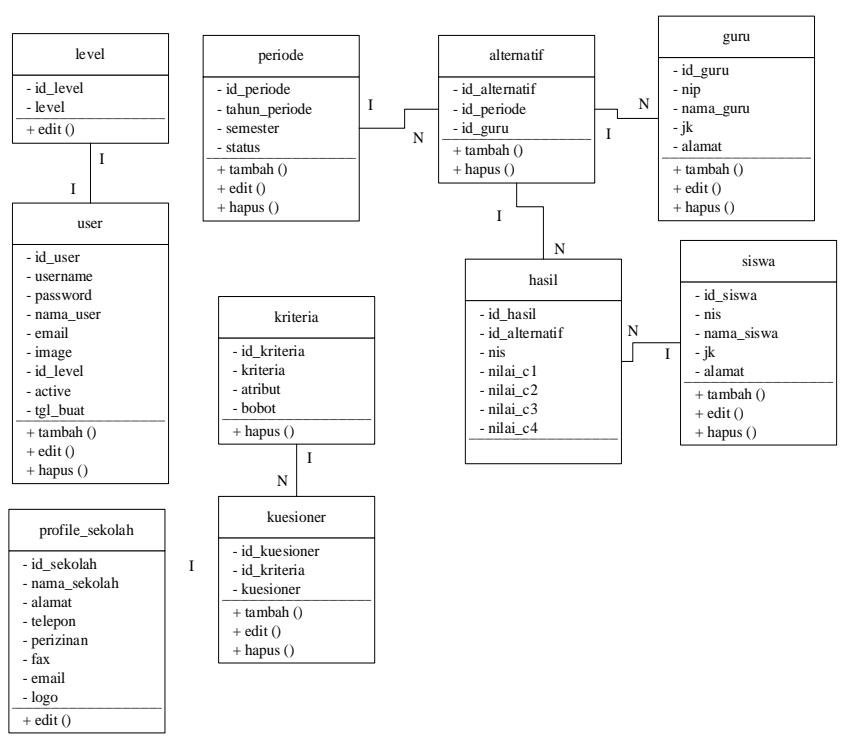

Gambar 3. Class Diagram

\section{HASIL PENELITIAN}

4.1. Implementasi Rancangan Sistem

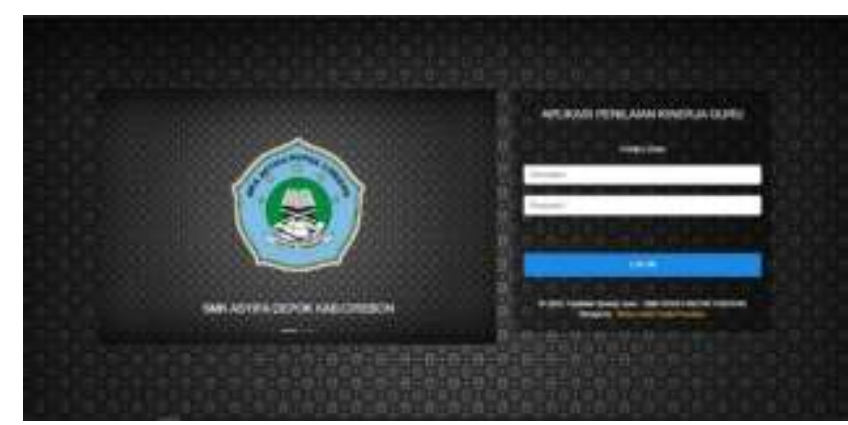

Gambar 4. Halaman Login Web

Gambar 4 menampilkan halaman login. Halaman ini dapat diakses oleh user admin, kepala sekolah, dan guru.

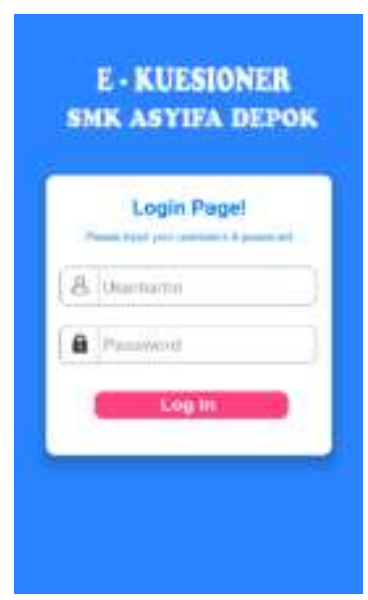

Gambar 5. Halaman Login Android 
Gambar 5 menampilkan halaman login. Halaman ini dapat diakses oleh user siswa.

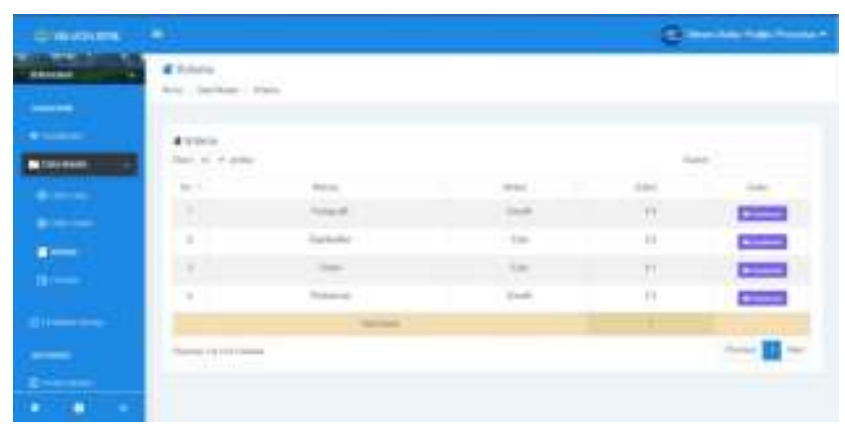

Gambar 6. Halaman Data Kriteria

Gambar 6 menampilkan tampilan halaman Data Kriteria yang hanya dapat diakses oleh Tata Usaha. Pada halaman ini terdapat button Kuesioner, yang berisi data kuesioner dari tiap-tiap kriterianya

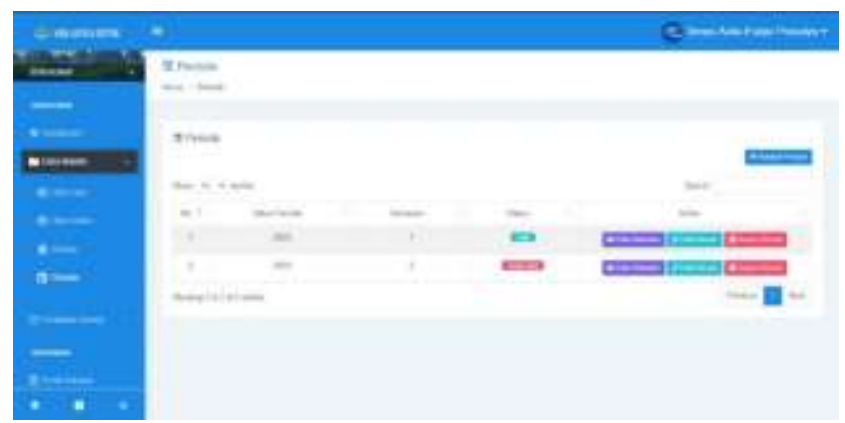

Gambar 7. Halaman Data Periode

Gambar 7 menampilkan tampilan halaman Data Periode yang hanya dapat diakses oleh Tata Usaha. Pada halaman ini terdapat button Data Penilaian, yang berisi data guru yang akan dinilai dari setiap periodenya.

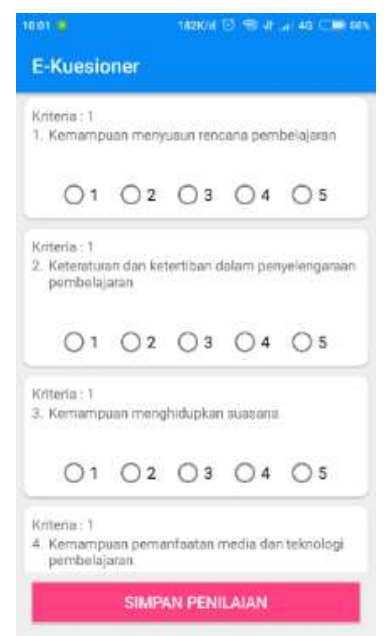

Gambar 8. Halaman Form Penilaian

Gambar 8 menampilkan tampilan halaman form penilaian yang dilakukan oleh siswa. Pada halaman siswa akan menilai kinerja guru yang akan dinilai.

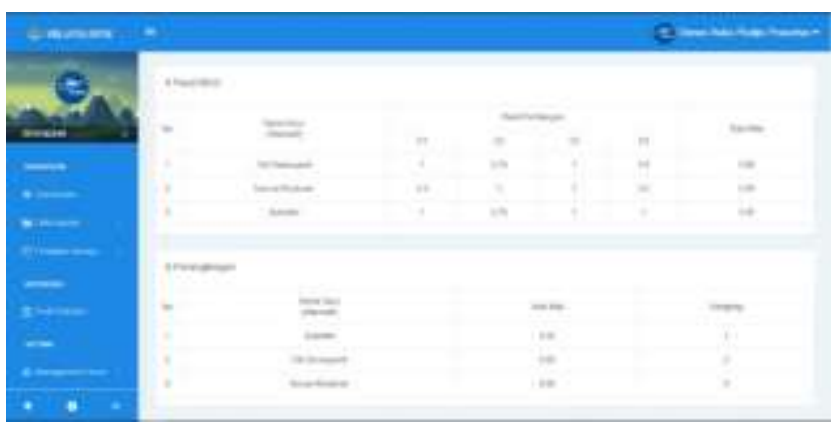

Gambar 9. Halaman Perangkingan

Gambar 9 menampilkan tampilan halaman Detail Perhitungan dengan menampilkan hasil perangkingan guru.

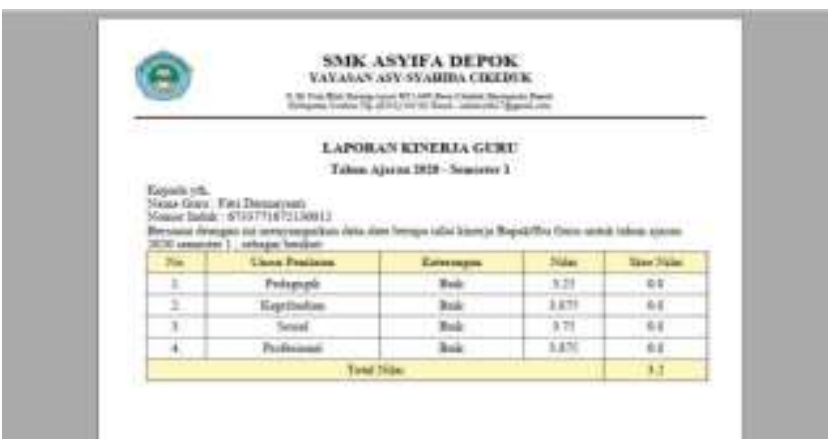

Gambar 10. Halaman Laporan Kinera Guru

Gambar 10 menampilkan hasil penilaian kinerja guru berdasarkan periode yang dipilih.

\section{KESIMPULAN DAN SARAN \\ 5.1. Kesimpulan}

Berdasarkan masalah dan pembahasan analisis yang telah diuraikan oleh penulis diatas maka dapat diambil kesimpulan terhadap aplikasi penilaian kinerja guru di SMK Asyifa Depok sebgai berikut :

1. Aplikasi ini lebih efektif dalam penilaian kinerja guru di SMK Asyifa Depok.

2. Dengan adanya sistem, hasil penilaian kinerja guru lebih objektif dan siswa dapat menilai kinerja guru.

3. Penerapan metode Simple Additive Weighting (SAW) ini dapat menunjang dalam pengambilan keputusan penilaian kinerja guru.

\subsection{Saran}

Adapun saran-saran yang penulis berikan untuk pengembangan aplikasi ini selanjutnya adalah:

1. Pengembangan penyajian data hasil penilaian dalam sistem lebih beragam, seperti grafik.

2. Perlu pengembangan yang lebih lanjut dalam proses pembuatan laporan, karena sistem ini masih sederhana dalam menampilkan hasil laporan.

3. Pengembangan fitur untuk menentukan rewards dan punishment dari hasil penilaian kinerja guru. 


\section{Daftar Pustaka}

[1] Dinas Pendidikan, Peraturan Menteri Pendidikan Nasional Nomer 16 Tahun 2007, 4 Juni 2018. [Online]. Tersedia: http:/www.disdik.jabarprov.go.id. [Diakses: 01 April 2020].

[2] Z. Kurniawan, "Sistem Pendukung Keputusan Penilaian Kinerja Guru untuk Rekomendasi Guru Tetap Berbasis Balanced Scorecard dengan Pendekatan Analytic Network Process," Pros. Semin. Nas. Sisfotek, vol. 3, no. 1, pp. 177-186, 2019.

[3] P. S. Sukanto, "SISTEM PENDUKUNG KEPUTUSAN PENILAIAN KINERJA KARYAWAN PT HARJAMUKTI JAYA MANDIRI MENGGUNAKAN METODE SIMPLE ADDITIVE WEIGHTING," JATISI (Jurnal Tek. Inform. dan Sist. Informasi), 2018, doi: 10.35957/jatisi.v5i1.121
[4] M. Budihardjo, Panduan Praktis Penilaian Kinerja Karyawan. Jakarta: Raih Asa Sukses, 2015.

[5] M. Amri and A. B. M. Assad, "PENGARUH KETELADANAN GURU TERHADAP AKHLAK PESERTA DIDIK KELAS IX MTS AS'ADIYAH PUTERI 1 SENGKANG KABUPATEN WAJO," Inspiratif Pendidik., 2020, doi: 10.24252/ip.v9i1. 13277.

[6] E. Ekastini, K. Kusrini, and E. T. Luthfi, "Penerapan Metode Fuzzy Analytical Hierarchy Process untuk SPK Penyeleksian Naskah Layak Terbit," Creat. Inf. Technol. J., 2018, doi: 10.24076/citec.2017v4i2. 103. 